\title{
Cyclooxygenase-2 and Ki67 Expression in Oral Leukoplakia: a Clinicopathological Study
}

\author{
Alper Sinanoglu', Merva Soluk-Tekkesin², Vakur Olgac ${ }^{2}$ \\ ${ }^{1}$ Oral Diagnosis Clinic, Department of Oral and Maxillofacial Radiology, Faculty of Dentistry, Kocaeli University, Kocaeli, \\ Turkey. \\ ${ }^{2}$ Department of Tumour Pathology, Institute of Oncology, Istanbul University, Istanbul, Turkey.
}

\author{
Corresponding Author: \\ Alper Sinanoglu \\ Oral Diagnosis Clinic, Department of Oral and Maxillofacial Radiology \\ Faculty of Dentistry, Kocaeli University \\ Yuvacik Yerleskesi, Basiskele, Kocaeli \\ Turkey \\ Phone: 00902623442222 \\ Fax: 00902623442109 \\ E-mail: alper.sinanoglu@kocaeli.edu.tr / alpersinanoglu@yahoo.com
}

\begin{abstract}
Objectives: Oral leukoplakia is a precancerous lesion of the oral mucosa. The upregulation of Ki67 and cyclooxygenase-2 has been reported in both dysplastic and non-dysplastic tissues. The aim of this clinicopathological study was to investigate the prognostic value of Ki67 and cyclooxygenase-2 expression for oral leukoplakia.

Material and Methods: A total of 50 samples were investigated and the study group consisted of 30 oral leukoplakia samples. Samples of 10 intact oral mucosa and 10 squamous cell carcinoma were included as negative and positive control groups, respectively. Epithelial dysplasia was defined as oral intraepithelial neoplasia (OIN) and classified into subgroups 1 - 3 . Tissue samples were assessed immunohistochemically for Ki67 and cyclooxygenase-2 expression. Clinicopathological correlations of oral leukoplakia patients were also investigated.

Results: All OIN 3 patients were non-smokers $(\mathrm{P}<0.05)$, and homogeneous oral leukoplakia lesions also presented OIN. Both cyclooxygenase-2 and Ki67 expression increased with the severity of lesions, which defined different subgroups (P $<$ 0.05), except there was no significant difference between the hyperkeratosis and OIN groups for Ki67 expression.

Conclusions: Cyclooxygenase-2 and Ki67 expression may have a prognostic value for the malignant transformation of oral leukoplakia.
\end{abstract}

Keywords: Cyclooxygenase 2; Ki-67 Antigen; leukoplakia; precancerous conditions.

Accepted for publication: 10 June 2015

To cite this article:

Sinanoglu A, Soluk-Tekkesin M, Olgac V. Cyclooxygenase-2 and Ki67 Expression in Oral Leukoplakia: a Clinicopathological Study.

J Oral Maxillofac Res 2015;6(2):e3

URL: http://www.ejomr.org/JOMR/archives/2015/2/e3/v6n2e3.pdf

doi: $10.5037 /$ jomr.2015.6203 


\section{INTRODUCTION}

Oral leukoplakia (OLEP) is defined as a white plaque of questionable risk that is diagnosed after excluding other known diseases or disorders that carry no additional risk for cancer [1]. OLEP is a clinical term that requires the application of strict diagnostic criteria for its classification [2,,$\underline{3}]$. OLEP may present a wide spectrum of histopathological patterns, including hyperkeratosis, epithelial dysplasia, carcinoma in situ, and squamous cell carcinoma (SCC) [4].

The Ki67 protein is localized to the nucleus in all actively dividing cells []ㅡ, and its expression level is proportional to the severity of dysplasia in OLEP [6]. The upregulation of Ki67 in both dysplastic and malignant tissues qualify Ki67 as a reliable marker of cell proliferation with prognostic significance $[\underline{6}, \underline{7}]$.

Cyclooxygenase (COX)-2 is an enzyme that catalyzes the synthesis of prostaglandins (PG) whose expression is associated with carcinogenesis owing to its roles in apoptosis, angiogenesis, inflammation and immunosuppression, invasion, and metastasis [8]. COX-2 expression was investigated for its relation with specific markers of these multiple mechanisms and correlations between high levels of COX-2 expression and carcinogenic progression were reported [9]. Additionally, COX-2 was reported to activate several classes of chemical carcinogens and its peroxidase function was contributed to the activation of procarcinogens. The mode of action of COX-2 in carcinogenesis was linked to PGs, especially of the E series $[\underline{8}, \underline{10}]$. Due to their effects on proliferation, angiogenesis, immune surveillance and apoptosis, increased synthesis of PGs are believed to be important in the pathogenesis of cancer [8-10]. COX-2 was found to be overexpressed in various carcinomas as well and high levels have been detected in SCC compared to normal epithelium [11-14].

The aim of this clinicopathological study was to assess the prognostic value of $\mathrm{COX}-2$ and $\mathrm{Ki67}$ expression for oral leukoplakia by determining their association with histomorphological data. To model the process of malignant transformation, samples of normal oral mucosa and squamous cell carcinoma were also investigated.

\section{MATERIAL AND METHODS Sample selection}

Tissue samples were collected from OLEP patients who were referred to the Department of Oral Diagnosis and Radiology in the Faculty of Dentistry at Marmara University, Istanbul, Turkey. Informed consent was obtained from the patients and the study was approved by the Ethics Committee of Marmara University (MAR-YC-2006-0123).

Patients using non-steroidal anti-inflammatory drugs at the time of diagnosis and in the month prior to their clinical examination were excluded from the study because of the potential effects of these agents on COX-2 levels [15]. Smoking and alcohol habits were recorded. With respect to the former, patients were divided into two groups. Smokers were individuals who were smoking regularly at the time of diagnosis and for at least 1 year prior. Non-smokers comprised patients who reported never having smoked as well as former smokers who had previously smoked but were not doing so at time of diagnosis [16]. Individuals who had one or more drinks three or more times per week were defined as habitual drinkers [17] and placed in the alcohol consumption group, with one unit of an alcoholic drink corresponding to $12 \mathrm{~g}$ of ethanol [18]. OLEP was defined according to criteria established by the World Health Organization [1]. All known and possible causative factors for alternate diagnoses were eliminated before biopsy. Clinical type and localization of the lesion were recorded. Clinically, leukoplakia was subdivided into homogeneous (C1) and non-homogeneous (C2) types. $\mathrm{C} 1$ was defined as flat, thin, and uniformly white; $\mathrm{C} 2$ referred to predominantly white, or white and red lesions that were irregular in shape, flat, nodular, or exophytic. A conservative excisional biopsy was performed for any lesion smaller than $2 \mathrm{~cm}$ in diameter; larger lesions were treated according to histopathological results by applying previously described management protocols $[2, \underline{4}]$.

Biopsied specimens were evaluated in the Department of Tumour Pathology at the Institute of Oncology of Istanbul University. Samples were stained with hematoxylin and eosin. The final diagnosis was confirmed by histopathological examinations and any other definable lesions were excluded. After microscopic evaluation, 30 samples of OLEP were retained as the study group. OLEP samples were divided into four subgroups according to histopathological features: hyperkeratosis (HK) and - when epithelial dysplasia was present - three oral intraepithelial neoplasia (OIN) subgroups classified according to severity [19] as mild dysplasia (OIN1), moderate dysplasia (OIN2), and severe dysplasia and carcinoma in situ (OIN3).

\section{Control groups}

A total of 20 samples, presenting 10 samples of intact normal oral mucosa $(\mathrm{N})$ and 10 samples of SCC were 
retrieved from the archives of the Department of Tumour Pathology and used as negative and positive control groups, respectively. The control tissue samples were used only in the immunohistochemical evaluation in order to form a gradually increasing model for the process of malignant transformation (Figure 1) and not evaluated in terms of habits of smoking and alcohol consumption.

\section{Immunohistochemistry}

The 50 tissue samples were embedded in paraffin and serial sections were cut at a thickness of $5 \mu \mathrm{m}$ that were collected on charged slides, then permeabilized and dried overnight in an autoclave at $56{ }^{\circ} \mathrm{C}$. After deparaffinization, sections were subjected to antigen retrieval by heating in a microwave four times for 5

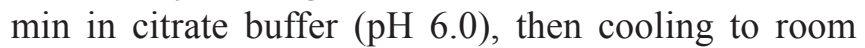
temperature and washing in phosphate buffered saline (PBS) for $5 \mathrm{~min}$. Endogenous peroxidase activity was quenched by incubating the sections in $3 \% \mathrm{H}_{2} \mathrm{O}_{2}$ followed by washes in distilled water. Slides were incubated for $2 \mathrm{~h}$ with rabbit anti-COX-2 (Thermo scientific, Lab Vision Corporation, Fremont, CA 94538-6406, USA) and rabbit monoclonal antiKi-67 (Thermo scientific, Thermo Fisher Scientific, Anatomical Pathology, Fremont, CA 94538, USA) antibodies, while negative control sections were treated with PBS. All slides were incubated with biotinylated goat anti-rabbit secondary antibody (TR015-BN; Lab Vision Corp.) for $25 \mathrm{~min}$, followed by a streptavidin-peroxidase reagent for $25 \mathrm{~min}$; the chromogenic substrate 3-amino-9-ethylcarbazole was used to visualize immunoreactivity. Sections were counterstained with Mayer's hematoxylin, covered with a coverslip, and evaluated under a light microscope (Olympus, Tokyo, Japan).

\section{Quantification of COX-2 and Ki67 staining}

COX-2 and Ki67 staining was evaluated by a pathologist who was blinded to the experimental protocol. Slides were scanned at low magnification under a light microscope and five areas with the highest degree of staining were selected for cell counts. Only nuclear staining was accepted as positive for Ki67. For COX-2, cytoplasmic and membranous staining was accepted as positive (Figure 2). Under magnification $\mathrm{x} 400$, the number of cells in the epithelium and in the tumour island of SCC specimens was counted. A cell with moderate to high staining was counted as positive. The immunoreactivity score was calculated as the mean percentage of positively stained cells to the total number of cells.

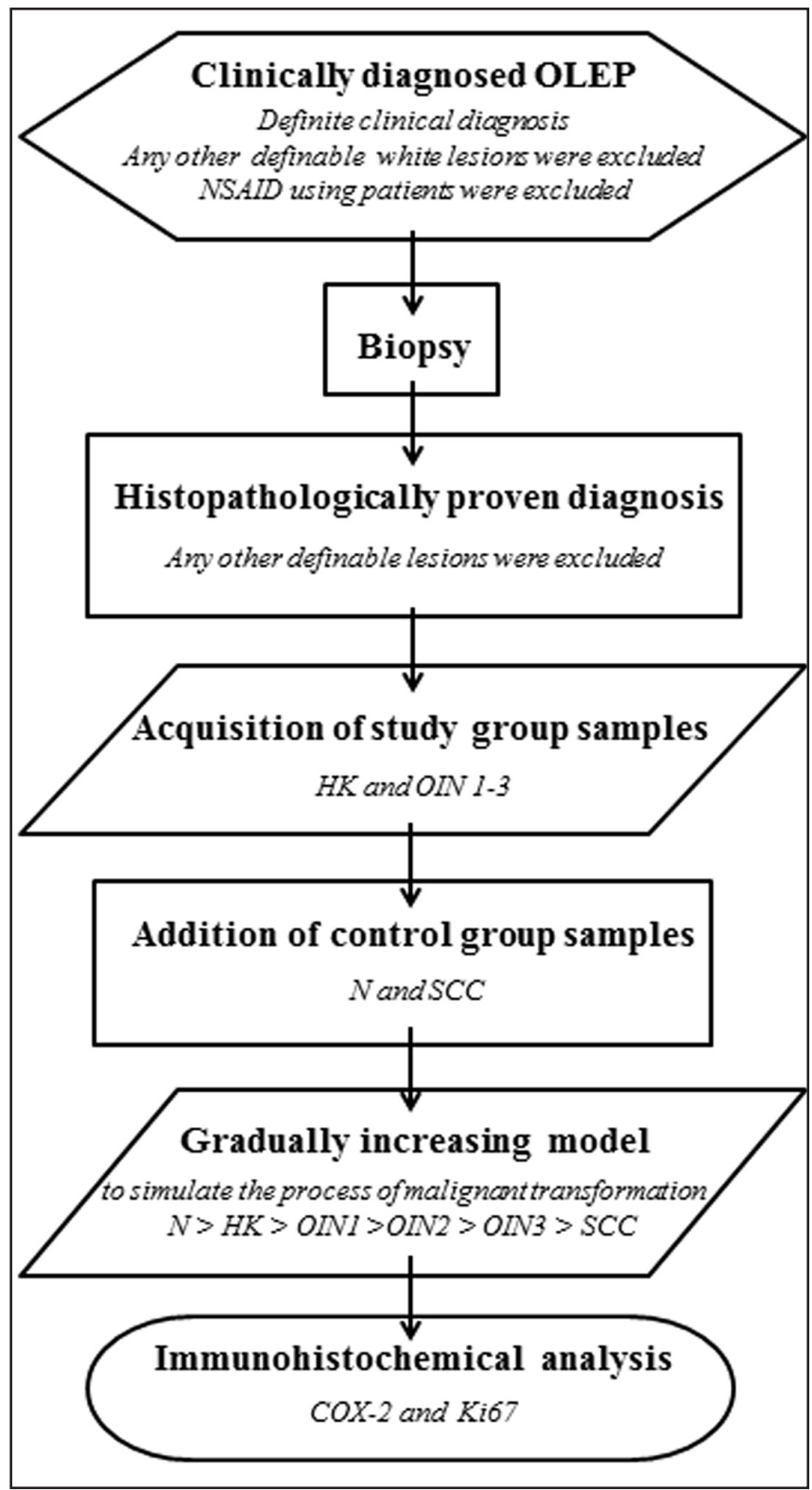

Figure 1. Flowchart of the study in sequential order with exclusion criteria. OLEP $=$ oral leukoplakia; NSAID $=$ non-steroidal anti-inflammatory drugs; $\mathrm{HK}=$ hyperkeratosis; $\mathrm{OIN}=$ oral intraepithelial neoplasia; $\mathrm{N}=$ normal mucosa; $\mathrm{SCC}=$ squamous cell carcinoma.

\section{Statistical analysis}

Statistical analyses were performed with SPSS 10.0 for Windows (SPSS Inc., Chicago, IL, USA). Mann-Whitney U test was used to compare variables among two groups. Kruskal-Wallis test was used to compare variables among multiple groups with MannWhitney U test (Bonferroni corrected) as a post-hoc test. Fisher's exact and Fisher-Freeman-Halton exact tests were used for qualitative comparisons of data. $\mathrm{P}$ values $<0.05$ were considered statistically significant. The means (M) and standard deviations (SD) of ages, expressions of COX-2 and Ki67 were expressed as (M [SD]). 


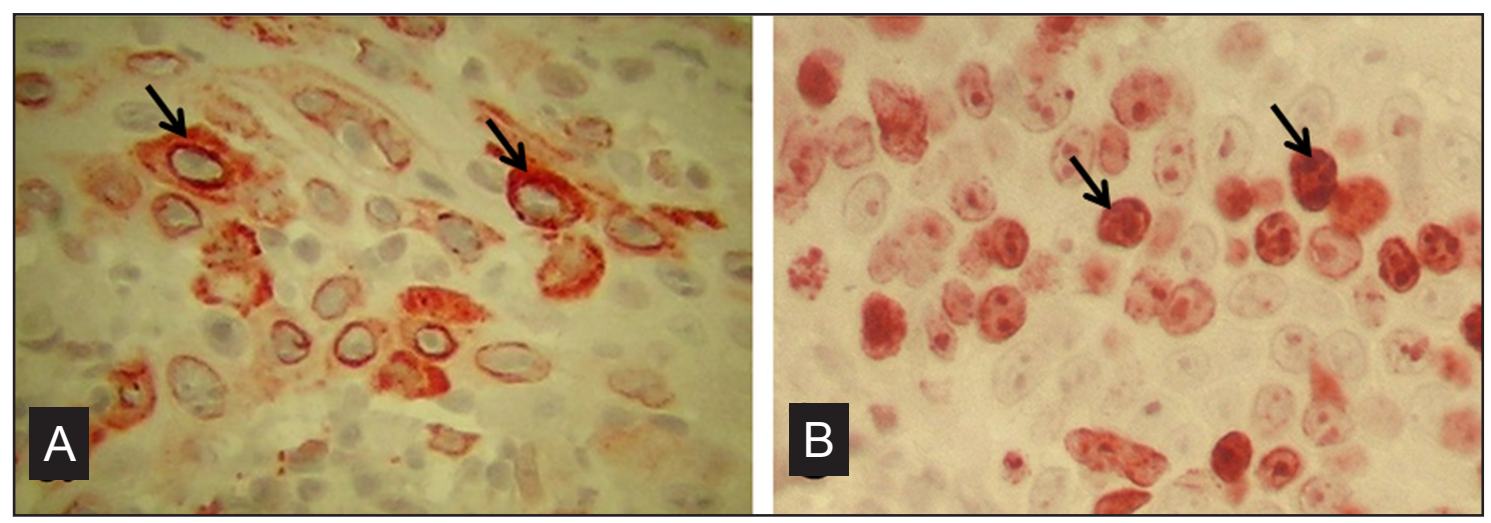

Figure 2. Immunoreactivity of COX-2 and Ki67 in oral intraepithelial neoplasia. A = COX-2 immunostain (original magnification $\mathrm{x} 400$ ). Note the strong reaction in the cytoplasms of oral intraepithelial neoplasia cells marked by arrows. $\mathrm{B}=\mathrm{Ki67}$ immunostain (original magnification $\mathrm{x} 400$ ). Positive staining was observed in the nucleus of oral intraepithelial neoplasia cells marked by arrows.

\section{RESULTS}

\section{Clinicopathological findings of OLEP patients}

Clinicopathological characteristics of the study group are shown in Table 1. Patients ranged in age from 30 to 75 years, $(54.33$ [11.03]), with 19 presenting HK (13 (68.4\%) males, 6 (31.6\%) females) and 11 presenting OIN (7 (63.6\%) males, $4(36.4 \%)$ females). The mean ages of the HK and OIN patients were similar (55.05 [10] years vs. 53.09 [12.93] years) $(\mathrm{P}=0.966)$. The occurrence of OIN was associated with a non-homogeneous clinical aspect $(\mathrm{P}=0.004)$, but was also observed in lesions with a homogeneous appearance (three OIN1 and two OIN2 patients). The homogeneous-type OLEP was more frequently observed in the HK group $(\mathrm{P}=0.004)$.
There was no difference between groups in terms of smoking and alcohol consumption $(\mathrm{P}=0.156$; $\mathrm{P}=0.327$; respectively). Lesions were more often localized on the tongue for OIN while buccal mucosa localization was higher for HK $(\mathrm{P}=0.002)$ (Table 2).

\section{Immunohistochemical findings}

COX-2 and Ki-67 expression increased relative to the degree of lesion severity in the histopathological subgroups, with the SCC group having the highest numbers of COX-2 - and Ki67-positive cells (Table $3)$. The mean number of COX-2 expressing cells was lowest in $\mathrm{N}$ tissue samples, higher in the SCC and OIN than in the HK group, and higher in the SCC than in the OIN group $(\mathrm{P}=0.0001)$.

Table 1. Clinicopathological characteristics of the study group

\begin{tabular}{|c|c|c|c|c|c|c|c|}
\hline & \multicolumn{2}{|c|}{ Study Group $(\mathrm{n}=\mathbf{3 0})$} & \multicolumn{3}{|c|}{ OIN Subgroups $(\mathrm{n}=11)$} & \multirow[b]{2}{*}{$\mathbf{P}$} \\
\hline & & $\begin{array}{c}\text { HK } \\
(n=19)\end{array}$ & $\begin{array}{c}\text { OIN } \\
(n=11)\end{array}$ & $\begin{array}{l}\text { OIN1 } \\
(n=5)\end{array}$ & $\begin{array}{c}\text { OIN2 } \\
(n=4)\end{array}$ & $\begin{array}{c}\text { OIN3 } \\
(n=2)\end{array}$ & \\
\hline \multirow{3}{*}{ Age } & Mean (SD) & $55.05(10.07)$ & $53.09(12.93)$ & $57.60(11.55)$ & $53.25(12.97)$ & $41.50(16.26)$ & \multirow{3}{*}{$0.966^{\mathrm{a}}$} \\
\hline & Median & 53 & 56 & 57 & 56.5 & 41.5 & \\
\hline & Min-max & $34-75$ & $30-71$ & $40-71$ & $35-65$ & $30-53$ & \\
\hline \multirow{2}{*}{ Gender } & $\mathbf{M}$ & $13(65)$ & $7(35)$ & $2(10)$ & $4(20)$ & $1(5)$ & \multirow{2}{*}{$1^{\mathrm{b}}$} \\
\hline & $\mathbf{F}$ & $6(60)$ & $4(40)$ & $3(30)$ & $0(0)$ & $1(10)$ & \\
\hline \multirow{2}{*}{ Smoking } & $\mathbf{S}$ & $17(70.8)$ & $7(29.2)$ & $3(12.5)$ & $4(16.7)$ & $0(0)$ & \multirow{2}{*}{$0.156^{\mathrm{b}}$} \\
\hline & NS & $2(33.3)$ & $4(66.7)$ & $2(33.3)$ & $0(0)$ & $2(33.3)$ & \\
\hline \multirow{2}{*}{ Alcohol } & $\mathbf{U}$ & $2(40)$ & $3(60)$ & $1(20)$ & $2(40)$ & $0(0)$ & \multirow{2}{*}{$0.327^{\mathrm{b}}$} \\
\hline & NU & $17(68)$ & $8(32)$ & $4(16)$ & $2(8)$ & $2(8)$ & \\
\hline \multirow{2}{*}{$\begin{array}{c}\text { Clinical } \\
\text { type }\end{array}$} & $\mathrm{C1}$ & $18(78.3)$ & $5(21.7)$ & $3(13)$ & $2(8.7)$ & $0(0)$ & \multirow{2}{*}{$0.004^{\mathrm{c}}$} \\
\hline & $\mathrm{C2}$ & $1(14.3)$ & $6(85.7)$ & $2(28.6)$ & $2(28.6)$ & $2(28.6)$ & \\
\hline
\end{tabular}

aStatistically no significant, Mann Whitney U test.

'Statistically no significant, Fisher's exact test.

'Statistically significant at the level $\mathrm{P}<0.01$, Fisher's exact test.

$\mathrm{P}$ values indicate HK vs OIN group comparisons.

$\mathrm{SD}=$ standard deviation; $\mathrm{HK}=$ hyperkeratosis; $\mathrm{OIN}=$ oral intraepithelial neoplasia; $\mathrm{n}=$ number of samples; $\mathrm{M}=$ male; $\mathrm{F}=$ female; $\mathrm{S}=$ smoker; $\mathrm{NS}=$ non-smoker; $\mathrm{U}=$ using; $\mathrm{NU}=$ non-user; $\mathrm{C} 1$ = homogenous type; $\mathrm{C} 2$ = non-homogenous type. 
Table 2. Localization of oral leukoplakia lesions by histopathological subgroups

\begin{tabular}{c|c|c|c|c|c|c}
\hline & \multicolumn{7}{|c}{ Site } \\
\cline { 2 - 7 } & Buccal & $\begin{array}{c}\text { Mandibular } \\
\text { gingiva }\end{array}$ & $\begin{array}{c}\text { Maxillary } \\
\text { gingiva }\end{array}$ & $\begin{array}{c}\text { Soft } \\
\text { palate }\end{array}$ & $\begin{array}{c}\text { Hard } \\
\text { palate }\end{array}$ & Tongue \\
\cline { 2 - 7 } & \multicolumn{7}{|c}{ (\%) } \\
\hline HK & $14(73.7)$ & $2(10.5)$ & $1(5.3)$ & $1(5.3)$ & $1(5.3)$ & $0(0)$ \\
\hline OIN & $3(27.3)$ & $0(0)$ & $1(9.1)$ & $0(0)$ & $2(18.2)$ & $5(45.5)$ \\
\hline OIN 1 & $1(20)$ & $0(0)$ & $1(20)$ & $0(0)$ & $2(40)$ & $1(20)$ \\
\hline OIN 2 & $2(50)$ & $0(0)$ & $0(0)$ & $0(0)$ & $0(0)$ & $2(50)$ \\
\hline OIN 3 & $0(0)$ & $0(0)$ & $0(0)$ & $0(0)$ & $0(0)$ & $2(100)$ \\
\hline
\end{tabular}

$\mathrm{N}=$ number of samples; $\mathrm{HK}=$ hyperkeratosis; $\mathrm{OIN}=$ oral intraepithelial neoplasia.

Table 3. COX-2 and Ki67 expressions in OLEP samples and controls

\begin{tabular}{|c|c|c|c|c|c|c|c|c|}
\hline & \multicolumn{4}{|c|}{ COX-2 expression } & \multicolumn{4}{|c|}{ Ki67 expression } \\
\hline & Mean (SD) & Median (min - max) & $\mathbf{P}^{\mathbf{d}}$ & Post-hoc $^{\mathrm{e}}$ & Mean (SD) & Median (min - max) & $\mathbf{P}^{\mathbf{d}}$ & Post-hoc $^{\mathrm{e}}$ \\
\hline${ }^{+} \mathbf{N}$ & $1.88(0.36)$ & $1.82(1.34-2.5)$ & \multirow{4}{*}{$0.001^{\mathrm{b}}$} & $\begin{array}{l}1<2^{\mathrm{b}} \\
1<3^{\mathrm{b}}\end{array}$ & $5.33(0.73)$ & $5.34(4.23-6.48)$ & \multirow{4}{*}{$0.001^{\mathrm{b}}$} & $\begin{array}{l}1<2^{b} \\
1<3^{b}\end{array}$ \\
\hline HK & $15.13(5.68)$ & $13.83(10.34-36.56)$ & & $\begin{array}{l}1<4^{b} \\
2<3^{a}\end{array}$ & $36.01(4.14)$ & $35.56(28.89-45.94)$ & & $\begin{array}{l}1<4^{b} \\
2<4^{b}\end{array}$ \\
\hline OIN & $27.22(11.31)$ & $26.42(12.37-46.35)$ & & $\begin{array}{l}2<4^{b} \\
3<4^{b}\end{array}$ & $39.49(6.94)$ & $37.77(31.63-53.39)$ & & $3<4^{b}$ \\
\hline$-\mathrm{SCC}$ & $73.63(4.68)$ & $74.25(65.56-79.65)$ & & & $74.66(6.15)$ & $74.05(66.7-85.91)$ & & \\
\hline OIN 1 & $17.27(3.43)$ & $17.61(12.37-21.01)$ & \multirow{3}{*}{$0.014^{\mathrm{a}, \mathrm{c}}$} & $5<6^{\mathrm{a}}$ & $37.9(4.43)$ & $37.77(31.63-43.87)$ & \multirow{3}{*}{$0.097^{\mathrm{c}}$} & - \\
\hline OIN 2 & $30.81(4.21)$ & $30.40(26.42-36.02)$ & & & $35.6(3.86)$ & $35.28(31.68-40.14)$ & & \\
\hline OIN 3 & $44.93(2.01)$ & $44.93(43.52-46.35)$ & & & $51.23(3.05)$ & $51.23(49.08-53.39)$ & & \\
\hline
\end{tabular}

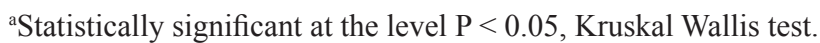

${ }^{\mathrm{b}}$ Statistically significant at the level $\mathrm{P}<0.01$, Kruskal Wallis test.

${ }^{c} \mathrm{P}$ values indicate OIN 1, OIN 2 and OIN 3 group comparisons.

${ }^{\mathrm{d}}$ Kruskal Wallis test.

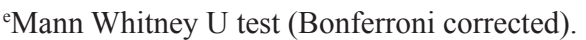

${ }^{+}$Positive control. - Negative control.

$\mathrm{P}$ values indicate $\mathrm{N}, \mathrm{HK}, \mathrm{OIN}$ and $\mathrm{SCC}$ group comparisons.

$\mathrm{SD}=$ standard deviation; OLEP = oral leukoplakia; $\mathrm{N}=$ normal mucosa; $\mathrm{HK}=$ hyperkeratosis; $\mathrm{OIN}=$ oral intraepithelial neoplasia; $\mathrm{SCC}=$ squamous cell carcinoma.

Among OIN subgroups, COX-2 expression also increased as a function of lesion severity. Ki-67 expression was detected in the nuclei of cells and in ascending order; these were $\mathrm{N}(5.33 \%)$, HK $(36.01 \%)$, OIN $(39.49 \%)$, and SCC $(74.66 \%)$. There was no significant difference between the HK and OIN groups, but a difference was found between SCC and OIN groups $(\mathrm{P}=0.0001)$ (Table 3$)$.

\section{DISCUSSION}

The prevalence of malignant transformations of OLEP is between $0.13 \%$ to $17.5 \%$ for observation periods ranging from 1 to 30 years [20]. Several factors are associated with an increased risk of malignant transformation, and the clinical appearance of OLEP is considered a major benchmark [21]. The occurrence of OIN is relatively low for the $\mathrm{C} 1$ clinical type, and higher rates of malignant transformation have been reported for the $\mathrm{C} 2$ type $[2,17, \underline{21}]$. In the present study, 5/23 (21.7\%) C1 and 6/7 (85.7\%) C2 OLEP cases presented OIN. However, given that OIN was detected in $\mathrm{C} 1$ cases, a biopsy is recommended as a mandatory procedure for all OLEP types.

Tobacco usage in different forms is the most common antecedent for OLEP lesions [20,21], with suggestions that some lesions may regress upon cessation of tobacco use $[\underline{3}, \underline{22}]$. According to one report, the risk for malignant transformation among individuals with SCC that had ceased using tobacco for more than 10 years was similar to that of non-smokers [23]. The patients in the present study were predominantly smokers $(80 \%)$, and two patients in the non-smokers group had ceased smoking for more than 10 years and both presented with HK. Nonetheless, due to dynamic nature of OLEP, regression is not expected in all OLEP cases [24]. Paradoxically, some OLEP 
lesions in non-smokers were reported to have worse prognosis than in smokers [16,22], and women without smoking habits had a higher risk of malignant transformation among the groups examined in one study [25]. Consistent with these findings, all the OIN 3 patients in the present study were non-smokers. It is suggested that the high-risk nature of lesions in nonsmokers is associated with intrinsic factors such as inherited or acquired predisposition, for which a more aggressive treatment strategy is recommended [26].

Alcohol consumption is another risk factor for OLEP, but its most potent effects are exerted through synergy with tobacco usage [2], with geographical variations reportedly playing a role [26]. In this study, a slightly higher rate of alcohol consumption was detected in OIN than in HK $(27.3 \%$ vs. $10.5 \%)$, although this difference was not statistically significant.

The increased proliferative capacity in OLEP has been confirmed by a higher expression level of Ki67 [7,27], which was proposed as a marker for the occurrence and severity of OIN in oral mucosa [28]. Its association with lesion severity underscores Ki67 expression as a prognostic factor for OLEP [7], which was suggested in the present study; the highest Ki67 expression was observed in SCC, followed by OIN and $\mathrm{HK}$, indicating that this marker of proliferation may be a predictor of progressive malignancy. On the other hand, although there was a gradual increase in Ki67 expression, no significant difference was detected between the HK and OIN groups.

COX-2 is an inducible enzyme whose expression is low or negative in most tissues, but a few hours after a single stimulation the enzymatic activity of COX-2 was reported to increase more than 10 -fold and then return promptly back to the basal level [9]. This expression is influenced by growth- and tumour-promoting factors, inflammatory stimuli, and oncogenes under a variety of pathophysiological conditions [10]. COX-2 expression has been implicated in the malignancy of SCC of the tongue as well as OIN [12] and COX-2 overexpression was found to be predictive of patient survival in SCC [13]
Elevated levels of COX-2 were also observed in the majority of dysplastic squamous epithelia and SCC, in contrast to the weak expression detected in normal esophageal tissue [14]. Another study reported progressively higher COX-2 levels in normal mucosa, OIN, and SCC [11]. Consistent with these results, here it was found that COX-2 expression was lowest in normal mucosa, higher in HK followed by OIN, and highest in SCC. Nevertheless, as a limitation of the present study, the number of the study group is low (30 samples of OLEP) and the subgroups are not equal (2 samples of OIN3). Therefore, further studies are required with larger populations in order to indicate COX-2 and Ki67 as prognostic markers of OLEP.

\section{CONCLUSIONS}

Our results suggest that cyclooxygenase-2 and Ki67 expression may have a prognostic value for evaluating the malignant transformation of oral leukoplakia, and that the etiopathogenesis of oral leukoplakia should be investigated in terms of risk factors other than smoking and alcohol consumption.

\section{ACKNOWLEDGMENTS AND DISCLOSURE STATEMENTS}

This article is dedicated to Prof. Dr. Semih Ozbayrak on the occasion of his retirement. The authors thank Prof. Dr. Semih Ozbayrak and Prof. Dr. Gulcin Erseven for their valuable input and support. Prof. Dr. Semih Ozbayrak has worked in the field of Oral Medicine and Dentomaxillofacial Radiology in Department of Oral Diagnosis and Radiology, Faculty of Dentistry, Marmara University, Istanbul, Turkey (1986 - 2013) and provided indispensable advice and guidance throughout this investigation.

The authors declare no conflicts of interest related to this study.

\section{REFERENCES}

1. Warnakulasuriya S, Johnson NW, van der Waal I. Nomenclature and classification of potentially malignant disorders of the oral mucosa J Oral Pathol Med. 2007 Nov;36(10):575-80. [Medline: 17944749] [doi: 10.1111/j.1600-0714.2007.00582.x]

2. van der Waal I, Schepman KP, van der Meij EH, Smeele LE. Oral leukoplakia: a clinicopathological review. Oral Oncol. 1997 Sep;33(5):291-301. [Medline: 9415326] [doi: 10.1016/S1368-8375(97)00002-X]

3. Brouns ER, Baart JA, Bloemena E, Karagozoglu H, van der Waal I. The relevance of uniform reporting in oral leukoplakia: definition, certainty factor and staging based on experience with 275 patients. Med Oral Patol Oral Cir Bucal. 2013 Jan 1;18(1):e19-26. [Medline: 23085711] [PMC free article: 3548640]

4. Sasaki K, Murakami T, Kawasaki M, Takahashi M. The cell cycle associated change of the Ki-67 reactive nuclear antigen expression. J Cell Physiol. 1987 Dec;133(3):579-84. [Medline: $\underline{\text { 3121642] }}$ 
5. Thomson PJ, Soames JV, Booth C, O’Shea JA. Epithelial cell proliferative activity and oral cancer progression. Cell Prolif. 2002 Aug;35 Suppl 1:110-20. [Medline: 12139714] [doi: 10.1046/j.1365-2184.35.s1.12.x]

6. Kövesi G, Szende B. Changes in apoptosis and mitotic index, p53 and Ki67 expression in various types of oral leukoplakia. Oncology. 2003;65(4):331-6. [Medline: 14707453] [doi: 10.1159/000074646]

7. Lin DT, Subbaramaiah K, Shah JP, Dannenberg AJ, Boyle JO. Cyclooxygenase-2: a novel molecular target for the prevention and treatment of head and neck cancer. Head Neck. 2002 Aug;24(8):792-9. [Medline: 12203806] [doi: $10.1002 /$ hed.10108]

8. van der Waal I. Potentially malignant disorders of the oral and oropharyngeal mucosa; terminology, classification and present concepts of management. Oral Oncol. 2009 Apr-May;45(4-5):317-23. [Medline: 18674954] [doi: 10.1016/j.oraloncology.2008.05.016]

9. Zha S, Yegnasubramanian V, Nelson WG, Isaacs WB, De Marzo AM. Cyclooxygenases in cancer: progress and perspective. Cancer Lett. 2004 Nov 8;215(1):1-20. [Medline: 15374627] [doi: 10.1016/j.canlet.2004.06.014]

10. Mohan S, Joel B, Epstein JB. Carcinogenesis and cyclooxygenase: the potential role of COX-2 inhibition in upper aerodigestive tract cancer. Oral Oncol. 2003 Sep;39(6):537-46. [Medline: 12798395] [doi: 10.1016/S1368-8375(03)00035-6]

11. Shibata M, Kodani I, Osaki M, Araki K, Adachi H, Ryoke K, et al. Cyclo-oxygenase-1 and -2 expression in human oral mucosa, dysplasias and squamous cell carcinomas and their pathological significance. Oral Oncol. 2005 Mar;41(3): 304-12. [Medline: 15743693] [doi: 10.1016/j.oraloncology.2004.09.009]

12. Renkonnen J, Wolff H, Paavonen T. Expression of cyclo-oxygenase-2 in human tongue carcinoma and its precursor lesions. Virchows Arch. 2002 Jun;440(6):594-7. [Medline: 12070598] [doi: 10.1007/s00428-002-0616-y]

13. Itoh S, Matsui K, Furuta I, Yasuo T. Immunohistochemical study on overexpression of cyclogenase-2: its importance as a prognostic predictor. Oral Oncol. 2003 Dec;39(8):829-35. [Medline: 13679206] [doi: 10.1016/S1368-8375(03)00105-2]

14. Yu HP, Xu SQ, Liu L, Shi LY, Cai XK, Lu WH, et al. Cyclooxygenase-2 expression in squamous dysplasia and squamous cell carcinoma of the esophagus. Cancer Lett. 2003 Aug 20;198(2):193-201. [Medline: 12957358] [doi: 10.1016/S0304-3835(03)00340-9]

15. Jaber MA, Porter SR, Gilthorpe MS, Bedi R, Scully C. Risk factors for oral epithelial dysplasia - the role of smoking and alcohol. Oral Oncol. 1999 Mar;35(2):151-6. [Medline: 10435149] [doi: 10.1016/S1368-8375(98)00106-7]

16. Freitas MD, Carion AB, Vila PG, Lopez AL, Garcia AG, Rey JMG. Clinicopathologic aspects of oral leukoplakia in smokers and nonsmokers. Oral Surg Oral Med Oral Pathol Oral Radiol Endod. 2006 Aug;102(2):199-203. [Medline: 16876063] [doi: 10.1016/j.tripleo.2005.12.009]

17. Lee JJ, Hung HC, Cheng SJ, Chen YJ, Chiang CP, Liu BY, et al. Carcinoma and dysplasia in oral leukoplakias in Taiwan: prevalence and risk factors. Oral Surg Oral Med Oral Pathol Oral Radiol Endod. 2006 Apr;101(4):472-80. [Medline: 16545712] [doi: 10.1016/j.tripleo.2005.07.024]

18. Petti S, Scully S. Association between different alcoholic beverages and leukoplakia among non- to moderatedrinking adults: a matched case-control study. Eur J Cancer. 2006 Mar;42(4):521-7. [Medline: 16427777] [doi: $10.1016 /$ j.ejca.2005.07.038]

19. Küffer R, Lombardi T. Premalignant lesions of the oral mucosa. A discussion about the place of oral intraepithelial neoplasia (OIN). Oral Oncol. 2002 Feb;38(2):125-30. [Medline: 11854058] [doi: 10.1016/S1368-8375(01)00050-1]

20. Amagasa T, Yamashiro M, Uzawa N. Oral premalignant lesions: from a clinical perspective Int J Clin Oncol. 2011 Feb;16(1):5-14. [Medline: 21225307] [doi: 10.1007/s10147-010-0157-3]

21. Ho MW, Risk JM, Woolgar JA, Field EA, Field JK, Steele JC, Rajlawat BP, Triantafyllou A, Rogers SN, Lowe D, Shaw RJ. The clinical determinants of malignant transformation in oral epithelial dysplasia. Oral Oncol. 2012 Oct;48(10): 969-76. [Medline: 22579265] [doi: 10.1016/j.oraloncology.2012.04.002]

22. Bouquot JE, Whitaker SB. Oral leukoplakia - rationale for diagnosis and prognosis of its clinical subtypes or "phases". Quintessence Int. 1994 Feb;25(2):133-40. [Medline: 8183979]

23. De Stefani E, Boffetta P, Oreggia F, Mendilaharsu M, Deneo-Pellegrini H. Smoking patterns and cancer of the oral cavity and pharynx: a case-control study in Uruguay. Oral Oncol. 1998 Sep;34(5):340-6. [Medline: 9861338] [doi: 10.1016/S1368-8375(98)00014-1]

24. Silverman JR, Gorksy M, Lozada F. Oral leukoplakia and malignant transformation. A follow-up study of 257 patients. Cancer. 1984 Feb 1;53(3):563-8. [Medline: 6537892] [doi: 10.1002/1097-0142(19840201)53:33.0.CO;2-F]

25. Schepman KP, van der Meij EH, Smeele LE, van der Waal I. Malignant transformation of oral leukoplakia: a followup study of a hospital-based population of 166 patients with oral leukoplakia from the Netherlands. Oral Oncol. 1998 Jul;34(4):270-5. [Medline: 9813722] [doi: 10.1016/S1368-8375(98)80007-9]

26. Johnson N. Tobacco use and oral cancer: a global perspective. J Dent Educ. 2001 Apr;65(4):328-39. [Medline: 11336118]

27. Carlos de Vicente J, Herrero-Zapatero A, Fresno MF, López-Arranz JS. Expression of cyclin D1 and Ki-67 in squamous cell carcinoma of the oral cavity: clinicopathological and prognostic significance. Oral Oncol. 2002 Apr;38(3):301-8. [Medline: 11978554] [doi: 10.1016/S1368-8375(01)00060-4]

28. Kurokawa H, Shinobu M, Murata T, Yamashita Y, Tomoyose T, Zhang M, et al. Immunohistochemical study of syndecan-1 down-regulation and the expression of P53 protein or Ki-67 antigen in oral leukoplakia with or without epithelial dysplasia. J Oral Pathol Med. 2003 Oct;32(9):513-21. [Medline: 12969225] [doi: 10.1034/j.1600-0714.2003.00117.x] 


\section{To cite this article:}

Sinanoglu A, Soluk-Tekkesin M, Olgac V. Cyclooxygenase-2 and Ki67 Expression in Oral Leukoplakia: a Clinicopathological Study.

J Oral Maxillofac Res 2015;6(2):e3

URL: http://www.ejomr.org/JOMR/archives/2015/2/e3/v6n2e3.pdf

doi: $10.5037 /$ jomr.2015.6203

Copyright (C) Sinanoglu A, Soluk-Tekkesin M, Olgac V. Published in the JOURNAL OF ORAL \& MAXILLOFACIAL RESEARCH (http://www.ejomr.org), 30 June 2015.

This is an open-access article, first published in the JOURNAL OF ORAL \& MAXILLOFACIAL RESEARCH, distributed under the terms of the Creative Commons Attribution-Noncommercial-No Derivative Works 3.0 Unported License, which permits unrestricted non-commercial use, distribution, and reproduction in any medium, provided the original work and is properly cited. The copyright, license information and link to the original publication on (http://www.ejomr.org) must be included. 